\title{
Satisfaction of deaf patients with the health care
}

Universidade Federal de Minas Gerais UFMG, Faculdade de Medicina, Programa de Pós-Graduação em Ciências Fonoaudiológicas, Belo Horizonte, Minas Gerais, Brasil.

Research support source: Fundação de Amparo à Pesquisa do Estado de Minas Gerais - FAPEMIG and Coordenação de Aperfeiçoamento de Pessoal de Nível Superior - Brazil (CAPES) - Finance Code 001.

Conflict of interests: Nonexistent

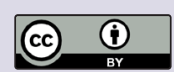

Received on: February 17, 2020 Accepted on: August 14, 2020

Corresponding address: Regiane Ferreira Rezende Rua Maria Macedo, 351 apt 1404, Nova Suiça

CEP: 30421-223 - Belo Horizonte Minas Gerais, Brasil

E-mail: regianelibras@gmail.com
Regiane Ferreira Rezende ${ }^{1}$ https://orcid.org/0000-0002-8509-9542

Leonor Bezerra Guerra ${ }^{1}$ https://orcid.org/0000-0002-6598-8238

Sirley Alves da Silva Carvalho' https://orcid.org/0000-0003-3705-9471

\section{ABSTRACT}

Purpose: to investigate the satisfaction of deaf people in relation to the health services, to characterize the sample regarding sociodemographic, socioeconomic, and selfperception of deafness, and to verify if there is an association between satisfaction with care,communication, professionals, and self-perception of deafness.

Methods: an observational, cross-sectional study conducted with a semi-structured questionnaire in 74 deaf adults. A descriptive analysis of the characterization of the sample and attendance, and an analysis of the association between satisfaction, professionals, self-perception, service used, and schooling level was performed, using the chi-square test. The level of significance adopted was $5 \%$.

Results: the sample was composed mainly of women (66.2\%), 18 to 28 years old (46.5\%), of socioeconomic class D (51.3\%), having finished high school (56.76\%), and employed as an office assistant or typist (90\%), 63.5\% self-declared as deaf, $51.3 \%$ were bilingual, and $54.4 \%$ were not satisfied with the medical care. There was a statistically significant difference between the level of satisfaction of the volunteers with the health care received in relation to the different health professionals who attended them $(p<0.05)$.

Conclusion: most of the population was not satisfied with medical care, although this service was most sought. The type of communication used by the professionals and the presence of an interpreter were not effective. It is necessary to implement strategies to ensure accessibility and comprehensive care to this population.

Keywords: Patient Satisfaction; Access to Health Services; Communication Barriers; Speech, Language and Hearing Sciences 


\section{INTRODUCTION}

Hearing loss $(\mathrm{HL})$ is defined by the Ministry of Health as the total or partial loss of the ability to hear'. It manifests invarious levels, reducing auditory sensibility and discrimination².

In an attempt to correct this hearing problem, health professionals may prescribe technological devices, such as hearing aids and cochlear implants ${ }^{3}$. However, these devices may not be efficient, and some deaf people may choose not to use them. In these cases, oral communication may suffer loss and increase barriers, as the counterparts do not share the same language ${ }^{4}$, which could interfere in their standard of living $^{3}$. Without imposing the major language of the country where they live, their right to communicate in their native tongue is secured in Brazil by Law no. 10.436, of 2002, which recognizes the Brazilian Sign Language (BSL) as a legal means of communication for the Brazilian deaf people ${ }^{5}$.

The implementation of the law by Decree no. $5.626 / 2005$, specifically in its chapter VII, secures to people with hearing loss the right to health care through the service network of the Brazilian Unified Health System(SUS), performed by professionals either trained to use BSL or assisted by translation or interpretation ${ }^{6}$.

If to comply with such secured rights the health professionals were in fact trained to communicate in the BSL, they would have the opportunity to know the peculiarities of the deaf culture and the healthcare for this group. Therefore, these professionals could search for strategies so that the communication with the deaf people would be effective, contributing to clearer information exchanged in the patient/health worker relationship ${ }^{4}$.

The law, as it is, presupposes changes in the health services, the training in BSL for these professionals included. It is also necessary to broaden the dialogue regarding the theme with these health workers, raising awareness of the impact on the quality of health care for the deaf population.

Developing research that investigates the patient's perception regarding this patient/health professional relationship is essential to implement policies targeting the population with impairments of different kinds ${ }^{2}$.

In this context, knowing the characteristics of the health care aimed for the deaf and these patients' satisfaction with the care offered them contributes to planning actions intended to improve the quality of the service provided.
This study aimed to investigate the satisfaction of people with hearing impairment with the health services, to characterize the participants regarding their sociodemographic and socioeconomic data and their self-perception of impairment, and to verify whether there is a relationship between their satisfaction with the health care, the means of communication used, the health professionals, and the self-perception of impairment.

\section{METHODS}

This is an observational, analytical, cross-sectional study, approved by the Research Ethics Committee (REC) of the Universidade Federal de Minas Gerais UFMG, MG, Brazil, under evaluation report no. 06950212.5.0000.5149. This study is an integral part of actions taken by the Projeto COMUNICA, tied to the NeuroEduca outreach program, developed in a partnership between the Departments of Morphology and Speech-Language-Hearing Pathology at UFMG.

The study was carried out in two philanthropic institutions of support to the deaf community in the Belo Horizonte metropolitan area, in Minas Gerais, Brazil, between April 2013 and February 2014. A survey in these two institutions revealed a total of 484 employees and registered users. The inclusion criteria were: being self-declared deaf or with hearing loss, over 18 years old, user or employee of any of the two institutions of support to the deaf community, and agreeing to participate in the research. The exclusion criterion was abstaining voluntarily from participating in the research. Considering the exclusion criterion, the eligible population had 74 participants.

The data were collected with a semi-structured questionnaire designed by the researchers, composed of three parts, each one addressing different aspects of the participant, their care for their own health, and their perspectives for improvements in the health care: 1) the participants' characteristics: sex, age, profession, means of communication used, the term they used in their self-perception of hearing loss, schooling level, type of health service used, and socioeconomic data, according to the Critério Brasil 7 ; 2) the communication strategy used with health workers: physician, nutritionist, dentist, speech-language-hearing therapist, and psychologist, and satisfaction level regarding the general care provided by each health worker; 3 ) the user's perspective for the improvement of the health care of deaf people. The third part was presented with open-ended questions (Annex 1). 
In this study, only the first and second parts were analyzed.

The participants answered the questionnaire individually, in a separate room, in the facilities of the philanthropic institutions or the participant's workplace, in a single meeting with the researcher, lasting approximately 15 minutes, using the means of communication they desired. The collection procedure could happen in three ways: a) the participants answered their own questionnaire; b) the researcher interpreted the questions in BSL and the participant filled out the questionnaire, c) the researcher interpreted the questions in BSL, received the answers from the participant in BSL, and filled in the questionnaire as well, always checking with the participant, by means of BSL communication, the accuracy of the registered answer. In any of the cases, the researchers helped the participants while the questionnaire was being administered, in case it was requested.

For the satisfaction level regarding the care evaluation, in the second part, the alternatives were referred on a Likert-type standardized scale, with five possibles cores, namely: 5 - very good; 4 - good; 3 - average; 2 - poor; and 1 - very poor. The answer options were presented for each field of health considered in the questionnaire.

In the occasion, all the information regarding the research and the Informed Consent Form (TCLE) were clarified, using the means of communication of the participant's choice. All the interviews were filmed using Digital Versatile Disc (DVD) video formats, for an accurate record of the statements and greater reliability of the data analysis.

A descriptive analysis was performed with the variables used in the study. For the categorical variables, the frequency distribution analysis was conducted. An association analysis was made between the satisfaction with the care provided by each health worker and the mean of communication used; the general satisfaction with the service; and the satisfaction with the care provided by each health worker regarding the hearing impairment. For that purpose, the chi-squared test was used, using the SPSS program, version 0.18 , and considering the $5 \%$ significance level.

\section{RESULTS}

The sample in this study was composed mostly of women (66.2\%) aged from 18 to 28 years (46.5\%), belonging to the social rank $D(51.3 \%)$, having finished high school $(56.76 \%)$, and reporting their occupation as an office clerk or typist (90\%). A great part of the participants self-declared themselves as deaf $(63.5 \%)$, bilingual $(51.35 \%)$, or able to communicate with BSL (36.49\%) (Table 1).

The private health service was responsible for $47.3 \%$ of the services in the last two years, but $44.59 \%$ of the studied population used the services of community health centers (UBS, its Portuguese acronym). A total of $33.8 \%$ visited the physician twice a year on average, and $27.42 \%$, three to four times a year (Table 1) 
Table 1. Sociodemographic and socioeconomic characteristics, their means of communication, self-perception regarding deafness, and type and frequency of health service used, regarding deaf people $(n=74)$ or employees in institutionsof support to the deaf community in the Belo Horizonte metropolitan area, Minas Gerais, Brazil, from 2013 and 2014

\begin{tabular}{|c|c|c|c|}
\hline & Characteristics & $\mathbf{n}$ & $\%$ \\
\hline \multirow{2}{*}{ Sex ${ }^{*}$} & Females & 49 & 66.22 \\
\hline & Males & 25 & 33.78 \\
\hline \multirow{5}{*}{ Age } & 18 to 28 years old & 34 & 46.58 \\
\hline & 29 to 39 years old & 23 & 31.51 \\
\hline & 40 to 50 years old & 13 & 17.81 \\
\hline & 51 to 60 years old & 2 & 2.74 \\
\hline & 61 to 70 years old & 1 & 1.37 \\
\hline \multirow{6}{*}{ Occupation** } & Office clerk & 23 & 32.86 \\
\hline & Typist & 40 & 57.14 \\
\hline & Disassembly & 1 & 1.43 \\
\hline & Data encryption & 4 & 5.71 \\
\hline & Assembly & 1 & 1.43 \\
\hline & BSL instructor & 1 & 1.43 \\
\hline \multirow{3}{*}{ Communication } & BSL & 27 & 36.49 \\
\hline & Oral & 9 & 12.16 \\
\hline & Bilingual & 38 & 51.35 \\
\hline \multirow{3}{*}{ Self-perception } & Deaf & 47 & 63.51 \\
\hline & Hearing-impaired & 13 & 17.57 \\
\hline & With hearing impairment & 14 & 18.92 \\
\hline \multirow{6}{*}{ Schooling level } & Completed middle school & 1 & 1.35 \\
\hline & Uncompleted middle school & 1 & 1.35 \\
\hline & Completed high school & 42 & 56.76 \\
\hline & Uncompleted high school & 20 & 27.03 \\
\hline & Completed higher education & 2 & 2.70 \\
\hline & Uncompleted higher education & 8 & 10.81 \\
\hline \multirow{4}{*}{ Social rank } & $\mathrm{C1}$ & 1 & 1.35 \\
\hline & $\mathrm{C} 2$ & 4 & 5.41 \\
\hline & $\mathrm{D}$ & 38 & 51.35 \\
\hline & $\mathrm{E}$ & 31 & 41.89 \\
\hline \multirow{3}{*}{ Health Service $^{\dagger}$} & Community health service & 33 & 44.59 \\
\hline & ER & 6 & 8.11 \\
\hline & Private & 35 & 47.30 \\
\hline \multirow{6}{*}{ Physician frequency } & Less than once a year & 9 & 14.52 \\
\hline & Once to twice a year & 21 & 33.87 \\
\hline & 3 to 4 times a year & 17 & 27.42 \\
\hline & Every 2 months & 4 & 6.45 \\
\hline & Once a month & 4 & 6.45 \\
\hline & More than once a month & 7 & 11.29 \\
\hline
\end{tabular}

Captions: Brazilian Sign Language - BSL | Emergency Room - ER | * 1 participant didnot answer this question | ** 4 participants did not answer this question | $\dagger$ The participant could check more than one alternative 
There was no statistically significant relationship between the general satisfaction with the service and the communication strategy used by the health worker, except for two situations (Table 2): The use of speech by the speech-language-hearing therapist, as the health workers that also used speech,were better evaluated $(p=0.001)$; and regarding the medical care, in which the participant was more satisfied when they went to the appointment accompanied by a hired interpreter, in comparison to the participant that went accompanied by a volunteer interpreter $(p=0.024)$.

Table 2. General satisfaction with the service* executed by each health worker and the communication strategy used by each professional, of deaf people $(n=74)$ users or employees of the support institutions to the deaf community in the metropolitan area of Belo Horizonte, Minas Gerais, Brazil, from 2013 to 2014

\begin{tabular}{|c|c|c|c|c|c|c|c|c|c|c|c|c|c|c|c|}
\hline \multirow{3}{*}{$\begin{array}{l}\text { Communication } \\
\text { Strategy }\end{array}$} & \multicolumn{3}{|c|}{ Professional } & \multicolumn{3}{|c|}{ Professional } & \multicolumn{3}{|c|}{ Professional } & \multicolumn{3}{|c|}{ Professional } & \multicolumn{3}{|c|}{ Professional } \\
\hline & \multicolumn{3}{|c|}{ Physician } & \multicolumn{3}{|c|}{ Nutritionist } & \multicolumn{3}{|c|}{ Dentist } & \multicolumn{3}{|c|}{$\begin{array}{l}\text { Speech-Language-Hearing } \\
\text { therapist }\end{array}$} & \multicolumn{3}{|c|}{ Psychologist } \\
\hline & $n$ & $\%$ & Meanscore & $n$ & $\%$ & Meanscore & $\mathrm{n}$ & $\%$ & Meanscore & $\mathrm{n}$ & $\%$ & Meanscore & $n$ & $\%$ & Meanscore \\
\hline Speech & 16 & 23.53 & 4.25 & 4 & 36.36 & 0 & 17 & 31.48 & 4.18 & 7 & 43.75 & 4.43 & 5 & 41.67 & 4.6 \\
\hline Writing & 9 & 12.24 & 3.67 & 1 & 9.09 & 0 & 9 & 16.67 & 4.11 & 2 & 12.5 & 4.00 & 0 & 0 & 0 \\
\hline Gestures & 3 & 4.41 & 0 & 1 & 9.09 & 0 & 2 & 3.7 & 4.5 & 0 & 0 & 0 & 0 & 0 & 0 \\
\hline Lipreading & 8 & 11.76 & 3.5 & 3 & 27.27 & 4 & 7 & 12.96 & 3.86 & 3 & 18.75 & 3.67 & 1 & 8.33 & 0 \\
\hline BSL & 1 & 1.47 & 0 & 0 & 0 & 0 & 3 & 5.56 & 4 & 3 & 18.75 & 0 & 3 & 25 & 4.67 \\
\hline Volunteer interpreter & 3 & 4.41 & 3.33 & 0 & 0 & 0 & 0 & 0 & 0 & 0 & 0 & 0 & 0 & 0 & 0 \\
\hline Hired interpreter & 3 & 4.41 & 4.67 & 0 & 0 & 0 & 0 & 0 & 0 & 0 & 0 & 0 & 0 & 0 & 0 \\
\hline $\begin{array}{l}\text { Hearing companion } \\
\text { who doesnot know } \\
\text { BSL }\end{array}$ & 25 & 37.76 & 3.68 & 2 & 18.18 & 4.5 & 16 & 29.63 & 3.81 & 1 & 6.25 & 0 & 2 & 16.67 & 3.5 \\
\hline $\begin{array}{l}\text { Hearing companion } \\
\text { who knows BSL }\end{array}$ & 0 & 0 & 0 & 0 & 0 & 0 & 0 & 0 & 0 & 0 & 0 & 0 & 1 & 8.33 & 0 \\
\hline$P$ & \multicolumn{3}{|c|}{0.024} & \multicolumn{3}{|c|}{0.52} & \multicolumn{3}{|c|}{0.479} & \multicolumn{3}{|c|}{0.01} & \multicolumn{3}{|c|}{0.087} \\
\hline
\end{tabular}

Caption: Brazilian Sign Language - BSL

* General satisfaction with the service: Likert scale from 5 to 1 (5 - very good; 4 - good; 3 - average; 2 - poor; and 1 - very poor)

† The participant could check more than one alternative

The analysis of the general satisfaction with the care provided by each health worker indicated that most of the patients were not satisfied with the medical care. Out of the 74 participants, 68 attended medical care, of whom only $45.5 \%$ considered their satisfaction as "good" or "very good". However, no statistical relevance was observed (Table 3).

Table 3. Distribution of the results regarding the general satisfaction with the service provided by different health workers to deaf people $(n=74)$ or employees of institutions of support to the deaf community in the Belo Horizonte metropolitan area, Minas Gerais, Brazil, from 2013 to 2014

\begin{tabular}{|c|c|c|c|c|c|c|c|c|c|c|c|c|c|}
\hline \multirow[t]{2}{*}{$\begin{array}{l}\text { General } \\
\text { satisfaction }\end{array}$} & \multicolumn{2}{|c|}{$\begin{array}{l}\text { Physician } \\
(n=68)\end{array}$} & \multicolumn{2}{|c|}{$\begin{array}{l}\text { Nutritionist } \\
(\mathrm{n}=11)\end{array}$} & \multicolumn{2}{|c|}{$\begin{array}{l}\text { Dentist } \\
(n=54)\end{array}$} & \multicolumn{2}{|c|}{$\begin{array}{c}\text { Speech- } \\
\text { Language-Hearing } \\
\text { Therapist }(n=16)\end{array}$} & \multicolumn{2}{|c|}{$\begin{array}{l}\text { Psychologist } \\
(n=12)\end{array}$} & \multicolumn{2}{|c|}{$\begin{array}{l}\text { Other } \\
(n=30)\end{array}$} & \multirow[t]{2}{*}{ p-value } \\
\hline & $n$ & $\%$ & $n$ & $\%$ & $\mathrm{n}$ & $\%$ & $\mathrm{n}$ & $\%$ & $\mathrm{n}$ & $\%$ & $n$ & $\%$ & \\
\hline Very poor & 3 & 4.4 & 0 & 0.0 & 1 & 1.9 & 0 & 0.0 & 0 & 0.0 & 0 & 0.0 & \\
\hline Poor & 6 & 8.8 & 2 & 18.2 & 1 & 1.9 & 1 & 6.3 & 0 & 0.0 & 1 & 3.3 & \\
\hline Average & 28 & 41.2 & 2 & 18.2 & 16 & 29.6 & 2 & 12.5 & 5 & 41.7 & 10 & 33.3 & 0.254 \\
\hline Good & 27 & 39.7 & 7 & 63.6 & 30 & 55.6 & 11 & 68.8 & 4 & 33.3 & 16 & 53.3 & \\
\hline Very good & 4 & 5.9 & 0 & 0.0 & 6 & 11.1 & 2 & 12.5 & 3 & 25.0 & 3 & 10.0 & \\
\hline
\end{tabular}

* Chi-squared test significance level: $5 \%$. 
The general satisfaction considered "very good" was more frequent concerning the psychologist $(25 \%)$, followed by the speech-language-hearing therapist (12.5\%), the dentist (11.5\%), and the physician (5.9\%).

Even though they are patients with hearing loss, not all of them were undergoing speech-languagehearing therapy, as shown in Table 3. Only 15 participants reported attending a speech-language-hearing therapist.
Table 4 shows the results of the relationship between general satisfaction and the type of health service used, the schooling level, and their self-declared situation. The results reveal a statistically relevant relation ship between the medical care and the self-perception of impairment $(p=0.016)$, indicating that the participants that considered the service as good or very good declared themselves as deaf.

Table 4. Relation ship between general satisfaction with service*, self-perception on hearing impairment, used service, and number of years attending school, regarding the deaf patients $(n=74)$ or employees of institutions of support to the deaf community in the Belo Horizonte metropolitan area, Minas Gerais, Brazil, from 2013 to 2014

\begin{tabular}{|c|c|c|c|c|c|c|c|c|c|c|c|c|}
\hline \multirow{3}{*}{ Professional } & \multirow{3}{*}{$\begin{array}{c}\text { General } \\
\text { satisfaction }\end{array}$} & \multicolumn{3}{|c|}{ Self-declared } & \multirow{3}{*}{$p$-value } & \multicolumn{3}{|c|}{ Health service } & \multirow{3}{*}{$\mathrm{p}$-value } & \multicolumn{2}{|c|}{ Years in school } & \multirow{3}{*}{ p-value } \\
\hline & & Deaf & Hearing- & $\begin{array}{c}\text { With } \\
\text { hearing }\end{array}$ & & Public & $E^{* *}$ & Private & & \multicolumn{2}{|c|}{$<12$ years $\geq 12$ years } & \\
\hline & & $\mathbf{N}$ & $\mathrm{N}$ & $\begin{array}{c}\text { impairment } \\
\text { N }\end{array}$ & & N & $\mathbf{N}$ & N & & N & $\mathbf{N}$ & \\
\hline \multirow[b]{2}{*}{ Physician } & Very good/Good & $27(65.9)$ & $7(53.8)$ & $3(21.4)$ & \multirow[b]{2}{*}{$0.016^{*}$} & 17 (58.6) & $3(50.0)$ & $17(51.5)$ & \multirow[b]{2}{*}{0.833} & $9(50.0)$ & $28(56.0)$ & \multirow[b]{2}{*}{0.661} \\
\hline & $\begin{array}{l}\text { Average/Poor/ } \\
\text { Very poor }\end{array}$ & $14(34.1)$ & $6(46.2)$ & $11(78.6)$ & & $12(41.4)$ & $3(50.0)$ & $16(48.5)$ & & $9(50.0)$ & $22(44.0)$ & \\
\hline \multirow[b]{2}{*}{ Nutritionist } & Very good/Good & $2(50.0)$ & $2(66.7)$ & $0(0.0)$ & \multirow[b]{2}{*}{0.150} & $2(50.0)$ & $0(0.0)$ & $2(33.3)$ & \multirow[b]{2}{*}{0.632} & $1(50.0)$ & $3(33.3)$ & \multirow[b]{2}{*}{0.658} \\
\hline & $\begin{array}{l}\text { Average/Poor/ } \\
\text { Very poor }\end{array}$ & $2(50.0)$ & $1(33.3)$ & $4(100.0)$ & & $2(50.0)$ & $1(100.0)$ & $4(66.7)$ & & $1(50.0)$ & $6(66.7)$ & \\
\hline \multirow[b]{2}{*}{ Dentist } & Very good/Good & $11(36.7)$ & $5(41.7)$ & $2(16.7)$ & \multirow[b]{2}{*}{0.363} & $10(45.5)$ & $1(16.7)$ & $7(26.9)$ & \multirow[b]{2}{*}{0.261} & $5(35.7)$ & $13(32.5)$ & \multirow[b]{2}{*}{0.826} \\
\hline & $\begin{array}{l}\text { Average/Poor/ } \\
\text { Very poor }\end{array}$ & 19(63.3) & $7(58.3)$ & $10(83.3)$ & & $12(54.5)$ & $5(83.3)$ & $19(73.1)$ & & $9(64.3)$ & $27(67.5)$ & \\
\hline \multirow{2}{*}{$\begin{array}{l}\text { Speech- } \\
\text { Language- } \\
\text { Hearing } \\
\text { Therapist }\end{array}$} & Very good/Good & $1(14.3)$ & $2(66.7)$ & $0(0.0)$ & \multirow[b]{2}{*}{0.050} & $2(28.6)$ & $0(0.0)$ & $1(14.3)$ & \multirow[b]{2}{*}{0.608} & $0(0.0)$ & $3(25.0)$ & \multirow[b]{2}{*}{0.267} \\
\hline & $\begin{array}{l}\text { Average/Poor/ } \\
\text { Very poor }\end{array}$ & $6(85.7)$ & $1(33.3)$ & $6(100.0)$ & & $5(71.4)$ & $2(100.0)$ & $6(85.7)$ & & $4(100.0)$ & $9(75.0)$ & \\
\hline \multirow[b]{2}{*}{ Psychologist } & Very good/Good & $3(50.0)$ & $2(100.0)$ & $0(0.0)$ & \multirow[b]{2}{*}{0.054} & $2(100.0)$ & $0(0.0)$ & $3(37.5)$ & \multirow[b]{2}{*}{0.117} & $1(25.0)$ & $4(50.0)$ & \multirow[b]{2}{*}{0.408} \\
\hline & $\begin{array}{c}\text { Average/Poor/ } \\
\text { Very poor }\end{array}$ & $3(50.0)$ & $0(0.0)$ & $4(100.0)$ & & $0(0.0)$ & $2(100.0)$ & $5(62.5)$ & & $3(75.0)$ & $4(50.0)$ & \\
\hline \multirow[b]{2}{*}{ Other } & Very good/Good & $10(62.5)$ & $1(16.7)$ & $0(0.0)$ & \multirow[b]{2}{*}{$0.006^{*}$} & $3(30.0)$ & $1(33.3)$ & 7 (41.2) & \multirow[b]{2}{*}{0.838} & $2(28.6)$ & $9(39.1)$ & \multirow[b]{2}{*}{0.612} \\
\hline & $\begin{array}{c}\text { Average/Poor/ } \\
\text { Very poor }\end{array}$ & $6(37.5)$ & $5(83.3)$ & $8(100.0)$ & & $7(70.0)$ & $2(66.7)$ & $10(58.8)$ & & $5(71.4)$ & $14(60.9)$ & \\
\hline
\end{tabular}

* Chi-squared test significance level: 5\%. ** Emergency Room

\section{DISCUSSION}

This study opted out to call the participants as deaf people, according to the self-perception of most of the participants (63.5\%) (Table 1), and due to the group's heterogeneity. Its diversity encompassed the type, degree, and/or time of hearing loss, the means of communication they used, and the culture to which they belong ${ }^{8}$.

The fact that most of the participants were females (Table 1) can be related to the importance that women give to self-care and their willingness to participate in health-related research. In previous studies, the relationship between females and their greater usage of health services was reported ${ }^{9,10}$.

The most frequent means of communication in this study were bilingualism (51.35\%) and BSL (36.49\%) (Table 1). This reflects the historical change in the approach to hearing impairment in Brazil, shown by other authors, such as Nobrega et al. (2012) ${ }^{8}$, Lisse et al. (2012) ${ }^{11}$. The previously imposed oralism defended that deaf people should speak without the use of signs $^{8,11}$. However, when the BSL was officialized in Brazil, in $2002^{5}$, and the bilingual-bicultural education was adopted, this scenario started changing ${ }^{12}$, pointing to greater respect towards diversity and openness to include individual strategies. 
The participants schooling level, predominantly high school, can restrict their career options - office clerk and typist - with repercussion on the socioeconomic classification of the studied group, according to cutoff scores of Critério Brasil (51.3\% in class D) (Table 1). An integrative literature review on the inclusion of deaf people, carried out in Brazil in 2013, points out that this scenario could be a reflection of the lack of inclusion of deaf people in school environments and the job market $^{13}$.

Regarding health care, it was noted that the deaf person needs this service, since the studied group of deaf people attended, in the last two tears, not only private health services (47.3\%) but public as well $(44.59 \%)$, visiting a physician at least once a year (85.48\%) (Table 1). Hence, health services should be prepared to welcome people with hearing impairment, ensuring accessibility to this group. To provide services that offer better conditions to approach deaf patients, like professionals trained in the sign language ${ }^{6}$, quality and equal care must be provided to groups with specific demands.

Health workers must be informed about the law and be trained to use the BSL. Thus, they would actually comply with the law, providing to the hearing-impaired person the opportunity for better care for their health, fostering more humane assistance.

A recent study, conducted in the Federal District, to trace a regional overview of the knowledge of BSL by health workers and their perception of care towards an unaccompanied deaf patient, point out the importance of implementing or broadening the study of BSL before and during graduation in health-oriented programs ${ }^{14}$.

Although this study has not demonstrated a statistically relevant relationship between communication strategy and the general satisfaction with professional health care, the patient that went to the physician accompanied by a professional interpreter, hired by the deaf person, was more satisfied with the service provided by the professional (Table 2). However, it is worth mentioning that most of the studied population (54.4\% out of 68 participants), was not satisfied with the medical care, since they graded it as "very poor" (4.4\%), "poor" (8.8\%), and "average" (41.2\%) (Table 2).

The presence of professional interpreters is legally secured in Brazil through the Law no. 10,436, of April $24,2002^{5}$, as stated in the 3rd article;

"the public institutions and accredited companies of public services and health assistance must ensure adequate care and treatment to those with hearing loss, following the existing legislation ${ }^{5}$ ".

However, Oliveira et al. (2015) ${ }^{15}$ showed a different reality at Fundação Centro de Atendimento à Pessoa Portadora de Deficiência (Center for the Assistance of People with a Disability - FUNAD), in João Pessoa, Paraíba, Brazil. In their study, they evaluated how deaf people understand communication with health workers and the meaning of the presence of an oral companion as an interpreter, during the care in the public network of health services. The research revealed that the population of 11 deaf people interviewed preferred to be assisted by professionals that knew sign language, to establish direct communication, keeping his privacy and independence.

According to the means of communication, in the present study, the oral speech was pointed as the most frequent means in speech-language-hearing therapy, and the second most frequent in medical care (Table 2).

According to Oliveira et al. $(2015)^{15}$, oral or written communications are still the most used means in appointments between health workers and patients. In addition, the results pointed out that strategies like lipreading and reading were not efficient for effective communication. The authors concluded that qualification with a specific minor degree in the culture and language of deaf people would be a determining factor to minimize the difficulties reported by deaf people who search for health services.

In the present study, lipreading was not an efficient strategy either, being the fourth most used means of communication in the services with a physician and dentist, and the third with a speech-language-hearing therapist (Table 2). This strategy requires a lot of attention because many phonemes are reproduced with similar points of articulation ${ }^{16}$, which can hinder comprehension, leading to loss of information.

Regarding the requirement of BSL studies in healthoriented programs, only the speech-language-hearing therapists are provided by law ${ }^{6}$, as it establishes an obligatory curricular subject in the Speech-languagehearing Pathology programs. Hence, since there is no legal regulation yet referring to the course load and its modality, if in-person or remote ${ }^{17}$, the students are not being adequately trained for effective communication with deaf patients during their professional practice. Regarding other health-related programs, there is no 
initiative whatsoever that ensures the training in sign language in its initial education.

In this regard, studies ${ }^{16,18}$ report the difficulties in attending these patients and the importance of the continuous training of these health workers, thus assuring, de facto, the access of deaf people to communication. A study with a qualitative approach with health managers carried out in Porto Alegre, Rio Grande do Sul, in 2013, revealed that community health workers search for different tools to remedy the difficulties in communication with deaf people and that the professional stance, in general, expresses discomfort and unpreparedness to care for this population ${ }^{19}$.

Beyond the importance of effective communication, health literacy is another important ability in the process of interaction between health workers and patients, since the information and orientations must be comprehended to be properly carried out, without affecting the subject's health condition, as clarified by Passamai et al. (2012) ${ }^{20}$.

The fact that $51.3 \%$ of the participants in this study were bilingual (Table 1) can be an influential factor in user satisfaction. If the patient has the alternative of oral language, the lack of health worker's training in BSL will not totally compromise the service. The idea is subject to argument, due to data in the integrative review by Oliveira et al. (2015) ${ }^{15}$, that suggests that when deaf patients and physicians meet, they encounter communicative barriers that compromise the link to be established and the care to be provided, and it may harm the diagnosis and treatment ${ }^{21}$.

In this regard, it is believed that if the communication is not restricted to BSL, it can be effective, diminishing harms and minimizing the difficulties for better-quality care.

Poor education can also contribute to a less rigorous evaluation, by the deaf people themselves, of their health care, considering that just $2.7 \%$ of the participants had college education (Table 1). A study about patient satisfaction in Brazil pointed out education as an influencing factor in health care satisfaction ${ }^{22}$. The population with higher schooling levels tends to be more demanding of quality service and, therefore, has shown to be less satisfied ${ }^{23}$.

The investigation around patient satisfaction is a way of evaluating the efficiency of health services and to orient corrective measures to be implemented in them, aiming for real contributions incaution and health care ${ }^{24,25}$. The satisfaction has been an important component in health evaluation results, regarding the received or provided care, obtaining information that benefits the coordination of these services and its users ${ }^{26}$.

The removal of barriers in health services used by deaf people provides equalitarian possibilities, when compared with people with no impairments ${ }^{27}$, and promotes greater access for the group to better health conditions. Thus, investing in the initial education of the futures health worker and training the already practicing professionals about deaf culture and BSL, stimulating health promotion actions and disease prevention, oriented to deaf people, and monitoring the user satisfaction can be relevant contributions for making the deaf person very satisfied with a better caring for their health.

\section{CONCLUSION}

Most of the participants of this study were women 18 to 28 years old, in social rank $D$, having finished high school, self-declared deaf, and bilingual communicators. They showed dissatisfaction with the medical care and satisfaction with the service of other health workers. Also, the physician was the professional most required by this group, as well as private services.

Regarding the relationship between general satisfaction and the care given by each health worker, the study reveals a greater satisfaction with the speechlanguage-hearing therapy.

These results point to a need for implementing BSL and deaf culture training actions in undergraduate and continuing education programs for these professionals. Besides, it is necessary to structure health care so that deaf people can have adequate access, with human resources that achieve an efficient and good quality communication with this group, promoting better care to the deaf.

\section{ACKNOWLEDGMENTS}

Gratitude is extended to the Federação Nacional de Educação e Integração dos Surdos - FENEIS, the Associação dos Surdos de Minas Gerais - ASMG, the third-party companies that coordinate FENEIS, theTradutores e Intérpretes da Língua Brasileira de Sinais- TILS, there search participants, and the Fundação de Amparo à Pesquisa do Estado de Minas Gerais - FAPEMIG for the financial support, regarding the Master's program scholar ship of Regiane Ferreira Rezende, and the Projeto de Extensão Universitária COMUNICA. 
Thiss tudy was financed in part by the Coordenação de Aperfeiçoamento de Pessoal de Nível Superior Brazil (CAPES) - Finance Code 001.

\section{REFERENCES}

1. Brasil. Ministério da Saúde. Secretaria de Atenção à Saúde. Política Nacional de Saúde da Pessoa Portadora de Deficiência / Ministério da Saúde, Secretaria de Atenção à Saúde - Brasília: Editora do Ministério da Saúde, 2008. 72 p. - (Série E. Legislação em Saúde) ISBN 978-85-334-1399-3

2. Castro SS, Paiva KM, César CLG. Dificuldades na comunicação entre pessoas com deficiência auditiva e profissionais de saúde: uma questão de saúde pública. Rev. Soc. Bras. Fonoaudiol. 2012;17(2):128-34.

3. Miziara ID, Miziara CSMG, Tsuji RK, Bento RF. Bioethics and medical/legal considerations on cochlear implants in children. Braz. J. Otorhinolaryngol. 2012;78(3):70-9.

4. Magrini AM, Momensohn-Santos TM. Communication between employees of a health unit and deaf patients: a problem? Distúrb. Comun. 2014;26(3):550-8.

5. Brasil. Lei oㅜ 10.436, de 24 de abril de 2002. Dispõe sobre a Língua Brasileira de Sinais - Libras e dá outras providências. Diário Oficial da República Federativa do Brasil. Brasília. Acesso em mar. 2018. Disponível em http://www.planalto.gov.br/ccivil_03/ leis/2002/L10436.htm

6. Brasil. Decreto o 5.626 de 22 de dezembro de 2005. Regulamenta a Lei o 10.436, de 24 de abril de 2002, que dispõe sobre a Língua Brasileira de Sinais a LIBRAS, e o art. 18 da Lei 10.098 de 19 de dezembro de 2002. Diário Oficial da República Federativa do Brasil Brasília, DF. 23 de dezembro de 2005. Acesso em marc. 2018. Disponível em: http://www.planalto.gov.br/ccivil_03/_ato20042006/2005/decreto/d5626.htm

7. Associação Brasileira de Empresas de Pesquisa - ABEP - Associação Brasileira de Empresas de Pesquisa - 2003 com base no Levantamento Sócio Econômico - 2000 - IBOPE. [acesso em 18 novembro 2013]. Disponível: http://www.abep.org

8. Nóbrega JD, Andrade AB, Pontes RJS, Bosi MLM, Machado MMT. Identidade surda e intervenções em saúde na perspectiva de uma comunidade usuária de língua de sinais. Ciênc. Saúde Coletiva. 2012;17(3):671-9.
9. Moreira JPL, Moraes JR, Luiz RR. Utilização de consulta médica e hipertensão arterial sistêmica nas áreas urbanas e rurais do Brasil, segundo dados da PNAD 2008. Ciênc. Saúde Coletiva. 2011;16(9):3781-93.

10. Alves RF, Silva RP, Ernesto M, Lima AGB, Souza FM. Gênero e saúde: o cuidar do homem em debate. Psicologia: Teoria e Prática. 2011;13(3):152-66.

11. Lissi MR, Svartholm K, González M. El enfoque bilingüe en la educación de sordos: sus implicancias para la enseñanza y aprendizaje de la lengua escrita. Estudios Pedagógicos. 2012;38(2):299-320.

12. Fernandes S, Moreira LC. Políticas de educação bilíngue para surdos: o contexto brasileiro. Educ. Rev. 2014; edição especial(2):51-69.

13. Espote R, Serralha CA, Scorsolini-Comin F. Inclusão de surdos: revisão integrativa da literatura científica. Psico-USF. 2013;18(1):77-88

14. Gomes LF, Machado FC, Lopes MM, Oliveira RS, Medeiros-Holanda B, Silva LB et al. Conhecimento de Libras pelos médicos do Distrito Federal e atendimento ao paciente surdo. Rev. Bras. Educ. Med. 2017;41(4):551-6.

15. Oliveira YCA, Celino SDM, Costa GMC. Comunicação como ferramenta essencial para assistência à saúde dos surdos. Physis. 2015;25(1):307-20.

16. Miranda RS, Schubert CO, Machado WCA. Communication with people with hearing disabilities: an integrative review. J. Res.: Fundam. Care. 2014;6(4):1695-706.

17. Guarinello AC, Berberian AP, Eyng DB, Festa PSV, Marques JM, Bortolozzi KB. Libras discipline in speech-language therapy academic context. Rev. CEFAC. 2013;15(2):334-40.

18. Levino DA, Souza EB, Cardoso PC, Silva AC, Carvalho AETM. Libras na graduação médica: o despertar para uma nova língua. Rev. Bras. Educ. Méd. 2013;37(2):291-7.

19. Tedesco JR, Junges JR. Desafios da prática do acolhimento de surdos na atenção primária. Cad. Saúde Pública. 2013;29(8):1685-9.

20. Passamai MPB, Sampaio HAC, Dias AMI, Cabral LM. Letramento funcional em saúde: reflexões e conceitos sobre seu impacto na interação entre usuários, profissionais e sistema de saúde. Interface. 2012;16(41):301-14. 
21. Oliveira Y, Coura A, Costa G, França I. Communication between health professionals-deaf people: an integrative review. Journal of Nursing UFPE. 2015;9(2):957-64.

22. Hollanda E, Siqueira SAV, Andrade GRB, Molinaro A, Vaitsman J. Satisfação e responsividade em serviços de atenção à saúde da Fundação Oswaldo Cruz. Ciênc. Saúde Coletiva. 2012;17(12):3343-52.

23. Santiago RF, Mendes ACG, Miranda GMD, Duarte PO, Furtado BMASM, Souza WV. Quality of care in the family healthcare units in the city of Recife: user perception. Ciênc. Saúde Coletiva. 2013;18(1):35-44.

24. Mendes F, Mantovani MF, Gemito ML, Lopes MJ. A satisfação dos utentes com os cuidados de saúde primários. Rev. Enf. Ref. 2013;(9):17-25.

25. Esher A, Santos EM, Magarinos-Torres RI, Azeredo TB. Construindo critérios de julgamento em avaliação: especialistas e satisfação dos usuários com a dispensação do tratamento do HIV/Aids. Ciênc. Saúde Coletiva. 2012;17(1):203-14.

26. Lyu H, Wick EC, Housman M, Freischlag JA, Makary MA. Patient satisfaction as a possible indicator of quality. Surgical Care. JAMA Surg. 2013;148(4):362-7.

27. Oliveira YCA, Celino SDM, França ISX, Pagliuca LMF, Costa GMC. Conhecimento e fonte de informações de pessoas surdas sobre saúde e doença. Interface. 2015;19(54):549-60. 
Annex 1 - Semi-structured questionnaire: deaf user satisfaction regarding health care

\section{SEMI-STRUCTURED QUESTIONNAIRE: DEAF USER SATISFACTION REGARDING HEALTH CARE}

Identification:

Age: Date of birth: Sex: $F() \mathrm{M}()$

Profession:

Home's Postal Code: Date: Interview Location:

Are you associated with any deaf institution? ( ) Yes ( ) No

If yes, which? ( ) Associação de Surdos ( ) FENEIS ( ) Other

If other, which?

Are you a user of Brazilian Sign Language - BSL? ( ) Yes

Are you Verbalized? ( ) Yes ( ) No

Are you Bilingual? ( ) Yes ( ) No

Do you use any other language or means of communication? ( ) Yes （ ) No

If yes, which?

Do you consider yourself: ( ) deaf ( ) hearing impaired ( ) with a hearing impairment

\section{Education:}

1. Are you literate ( ) Yes ( ) No

2. How many years did you study?

3. What is your qualification?

( ) Uncompleted middle school

( ) Completed middle school

( ) Uncompleted high school

( ) Completed high school

( ) Uncompleted higher education

( ) Bachelor's degree

Socioeconomic data:

4. In your house, there are: Items 01234 or +

\begin{tabular}{|c|c|c|c|c|c|}
\hline \multirow{2}{*}{ Items } & \multicolumn{5}{|c|}{ Quantity of Items } \\
\hline & 0 & 1 & 2 & 3 & 4 or + \\
\hline \multicolumn{6}{|l|}{ ColorTV } \\
\hline \multicolumn{6}{|l|}{ Radio } \\
\hline \multicolumn{6}{|l|}{ Bathroom } \\
\hline \multicolumn{6}{|l|}{ Vehicle } \\
\hline \multicolumn{6}{|l|}{ Monthlymaid } \\
\hline \multicolumn{6}{|l|}{ Washing machine } \\
\hline \multicolumn{6}{|l|}{ VHS player and/or DVD player } \\
\hline \multicolumn{6}{|l|}{ Fridge } \\
\hline Freezer (independent device or part of a double fridge) & & & & & \\
\hline
\end{tabular}

\section{Usage of health services:}

5. When you have a health problem you go to:

( ) The community health service ( ) An Emergency Room ( ) A Private Clinic （ ) Other

If other, which? 
6. With what frequency did you go to a health worker in the last couple of years?
( ) less than once a year
( ) once or twice a year
( ) 3 or 4 times a year
( ) every two months
( ) once a month
( ) more than once a month
( ) I don't know how to answer

7. Have you ever had a disease?

( ) Yes ( ) No ( ) I don't know how to answer

If yes, which?

8. Do you do any health treatment?

( ) Yes ( ) No If yes, which?

9. Do you take any medicine?

( ) Yes ( ) No If yes, which?

( ) Get your medicine from SUS ( ) Buy your medicine ( ) Buy at Popular Drugstores

\section{Communication and Objective evaluation of user satisfaction:}

10. Check the health workers you went to in the last couple of years?

( ) Physician. Which specialty:

( ) SUS ( ) Private

10.1. Which strategy did you use to communicate with them?
( ) Speech
( ) Writing
( ) Drawing
( ) Gestures
( ) Lipreading
( ) BSL - since the health worker knows sign language
( ) Family interpreter or volunteer friend
( ) Health institution interpreter
( ) Interpreter hired by the deaf person
( ) Hearing companion who doesn't know BSL
( ) Other:

10.2. How do you evaluate the service provided by the clerk or reception?
( ) Very good
( ) Good
( ) Average ( ) Poor
( ) Very poor

10.3. How do you evaluate the health worker care?
( ) Very good
( ) Good
( ) Average ( ) Poor
( ) Very poor

10.4. How do you evaluate your level of understanding when the professional talks directly to you?

( ) Very good ( ) Good ( )Average ( ) Poor ( ) Very poor

10.5. How do you evaluate the understanding of the health worker when you talk directly to him?

( ) Very good ( ) Good ( ) Average ( ) Poor ( ) Very poor 
10.6. How do you evaluate the health worker's understanding when the conversation is intermediated by an interpreter or companion that knows BSL?

( ) Very good ( ) Good ( ) Average ( ) Poor ( ) Very poor

10.7. How do you evaluate the health worker's understanding when the conversation is intermediated by a companion who doesn't know BSL?

( ) Very good ( ) Good ( )Average ( ) Poor ( ) Very poor

10.8. What is your satisfaction with the care in general?

( ) Very good ( ) Good ( ) Average ( ) Poor ( ) Very poor

11. ( ) Nutritionist.

( ) SUS ( ) Private

11.1. Which strategy did you use to communicate with this?
( ) Speech
( ) Writing
( ) Drawing
( ) Gestures
( ) Lipreading
( ) BSL - since the health worker knows sign language
( ) Family interpreter or volunteer friend
( ) Health institution interpreter
( ) Interpreter hired by the deaf person
( ) Hearing companion who doesn't know BSL
( ) Other:

11.2. How do you evaluate the service provided by the clerk or reception?

( ) Very good ( ) Good ( )Average ( ) Poor ( ) Very poor

11.3. How do you evaluate the health worker care?

( ) Very good ( ) Good ( )Average ( ) Poor ( ) Very poor

11.4. How do you evaluate your level of understanding when the professional talks directly to you?

( ) Very good ( ) Good ( ) Average ( ) Poor ( ) Very poor

11.5. How do you evaluate the understanding of the health worker when you talk directly to him?

( ) Very good ( ) Good ( ) Average ( ) Poor ( ) Very poor

11.6. How do you evaluate the health worker's understanding when the conversation is intermediated by an interpreter or companion that knows BSL?

( ) Very good ( ) Good ( )Average ( ) Poor ( ) Very poor

11.7. How do you evaluate the health worker's understanding when the conversation is intermediated by a companion who doesn't know BSL?

( ) Very good ( ) Good ( )Average ( ) Poor ( ) Very poor

11.8. What is your satisfaction with the care in general?

( ) Very good ( ) Good ( ) Average ( ) Poor ( ) Very poor 
12. ( ) Dentist.
( ) SUS
( ) Private

12.1. Which strategy did you use to communicate with this?
( ) Speech
( ) Writing
( ) Drawing
( ) Gestures
( ) Lipreading
( ) BSL - since the health worker knows sign language
( ) Family interpreter or volunteer friend
( ) Health institution interpreter
( ) Interpreter hired by the deaf person
( ) Hearing companion who doesn't know BSL
( ) Other:

12.2. How do you evaluate the service provided by the clerk or reception?

( ) Very good ( ) Good ( ) Average ( ) Poor ( ) Very poor

12.3. How do you evaluate the health worker care?

( ) Very good ( ) Good ( )Average ( ) Poor ( ) Very poor

12.4. How do you evaluate your level of understanding when the professional talks directly to you?

( ) Very good ( ) Good ( ) Average ( ) Poor ( ) Very poor

12.5. How do you evaluate the understanding of the health worker when you talk directly to him?

( ) Very good ( ) Good ( ) Average ( ) Poor ( ) Very poor

12.6. How do you evaluate the health worker's understanding when the conversation is intermediated by an interpreter or companion that knows BSL?
( ) Very good
( ) Good ( $)$ r
) Average ( ) Poor ( )
( ) Very poor

12.7. How do you evaluate the health worker's understanding when the conversation is intermediated by a companion who doesn't know BSL?
( ) Very good
( ) Good
) Average ( ) Poor
( ) Very poor

12.8. What is your satisfaction with the care in general?

( ) Very good ( ) Good ( ) Average ( ) Poor ( ) Very poor

13. ( ) Speech therapist.
( ) SUS
( ) Private

13.1. Which strategy did you use to communicate with this?
( ) Speech
( ) Writing
( ) Drawing
( ) Gestures
( ) Lipreading
( ) BSL - since the health worker knows sign language
( ) Family interpreter or volunteer friend 
( ) Health institution interpreter

( ) Interpreter hired by the deaf person

( ) Hearing companion who doesn't know BSL

( ) Other:

13.2. How do you evaluate the service provided by the clerk or reception?

( ) Very good ( ) Good ( ) Average ( ) Poor ( ) Very poor

13.3. How do you evaluate the health worker care?

( ) Very good ( ) Good ( )Average ( ) Poor ( ) Very poor

13.4. How do you evaluate your level of understanding when the professional talks directly to you?

( ) Very good ( ) Good ( ) Average ( ) Poor ( ) Very poor

13.5. How do you evaluate the understanding of the health worker when you talk directly to him?

( ) Very good ( ) Good ( ) Average ( ) Poor ( ) Very poor

13.6. How do you evaluate the health worker's understanding when the conversation is intermediated by an interpreter or companion that knows BSL?

( ) Very good ( ) Good ( ) Average ( ) Poor ( ) Very poor

13.7. How do you evaluate the health worker's understanding when the conversation is intermediated by a companion who doesn't know BSL?

( ) Very good ( ) Good ( )Average ( ) Poor ( ) Very poor

13.8. What is your satisfaction with the care in general?

( ) Very good ( ) Good ( ) Average ( ) Poor ( ) Very poor

14. ( ) Psychologist.

( ) SUS ( ) Private

14.1. Which strategy did you use to communicate with this?
( ) Speech
( ) Writing
( ) Drawing
( ) Gestures
( ) Lipreading
( ) BSL - since the health worker knows sign language
( ) Family interpreter or volunteer friend
( ) Health institution interpreter
( ) Interpreter hired by the deaf person
( ) Hearing companion who doesn't know BSL
( ) Other:

14.2. How do you evaluate the service provided by the clerk or reception?

( ) Very good ( ) Good ( ) Average ( ) Poor ( ) Very poor

14.3. How do you evaluate the health worker care?

( ) Very good ( ) Good ( )Average ( ) Poor ( ) Very poor 
14.4. How do you evaluate your level of understanding when the professional talks directly to you?

( ) Very good ( ) Good ( )Average ( ) Poor ( ) Very poor

14.5. How do you evaluate the understanding of the health worker when you talk directly to him?

( ) Very good ( ) Good ( ) Average ( ) Poor ( ) Very poor

14.6. How do you evaluate the health worker's understanding when the conversation is intermediated by an interpreter or companion that knows BSL?

( ) Very good ( ) Good ( )Average ( ) Poor ( ) Very poor

14.7. How do you evaluate the health worker's understanding when the conversation is intermediated by a companion who doesn't know BSL?

( ) Very good ( ) Good ( )Average ( ) Poor ( ) Very poor

14.8. What is your satisfaction with the care in general?

( ) Very good ( ) Good ( )Average ( ) Poor ( ) Very poor

15. ( ) Other. Which one?
( ) SUS
( ) Private

15.1. Which strategy did you use to communicate with this?
( ) Speech
( ) Writing
( ) Drawing
( ) Gestures
( ) Lipreading
( ) BSL - since the health worker knows sign language
( ) Family interpreter or volunteer friend
( ) Health institution interpreter
( ) Interpreter hired by the deaf person
( ) Hearing companion who doesn't know BSL
( ) Other:

15.2. How do you evaluate the service provided by the secretary or reception?

( ) Very good ( ) Good ( )Average ( ) Poor ( ) Very poor

15.3. How do you evaluate the health worker care?
( ) Very good
( ) Good
( ) Average ( ) Poor
( ) Very poor

15.4. How do you evaluate your level of understanding when the professional talks directly to you?

( ) Very good ( ) Good ( )Average ( ) Poor ( ) Very poor

15.5. How do you evaluate the understanding of the health worker when you talk directly to him?

( ) Very good ( ) Good ( )Average ( ) Poor ( ) Very poor

15.6. How do you evaluate the health worker's understanding when the conversation is intermediated by an interpreter or companion that knows BSL?

( ) Very good ( ) Good ( )Average ( ) Poor ( ) Very poor 
15.7. How do you evaluate the health worker's understanding when the conversation is intermediated by a companion who doesn't know BSL?
( ) Very good ( ) Good ( ) Average ( ) Poor ( ) Very poor

15.8. What is your satisfaction with the care in general?

( ) Very good ( ) Good ( ) Average ( ) Poor ( ) Very poor

16. Do you have any suggestions to improve deaf health care? 